\title{
INDEKS TOLERANSI ANTARUMAT BERAGAMA DI KABUPATEN LOMBOK TIMUR
}

\author{
Ahmad Tohri $^{1}$, Abdul Rasyad ${ }^{1 *}$, Sulaiman ${ }^{2}$, Umu Rosyidah $^{3}$ \\ ${ }^{1}$ Universitas Hamzanwadi, Indonesia \\ ${ }^{2}$ Universitas Gunung Rinjani, Indonesia \\ ${ }^{3}$ Universitas Islam Negeri Mataram, Indonesia \\ *e-mail: rasyad.iis@hamzanwadi.ac.id
}

\begin{abstract}
Abstrak
Realitas toleransi sebagai fakta sosial tidak akan memadai apabila dipotret hanya dari satu sisi yang tidak mampu mengungkap makna di balik fakta, karena toleransi tidak hanya berdimensi emik, tetapi juga berdimensi etik. Artikel ini bertujuan untuk memaparkan dan menjelaskan indeks toleransi antarumat beragama di Kabupaten Lombok Timur menurut perspektif fakta sosial sesuai kondisi sekarang. Penelitian ini meggunakan pendekatan kuantitatif metode survey. Pengumpulan data menggunakan teknik angket tertutup dan teknik focus group discussion (FGD). Analisis data menggunakan metode statistik deskriptif dan teknik analisis domain. Indeks toleransi antarumat beragama di Kabupaten Lombok Timur secara keseluruhan termasuk kategori tinggi dengan skor rata-rata 3.79. Dari dimensi emik, toleransi antarumat beragama masyarakat Lombok Timur yang tinggi merupakan fakta sosial yang nyata. Perbedaan indeks toleransi antarumat beragama antara hasil survey Puslitbang Bimas Agama dan Layanan Keagamaan Badan Litbang dan Diklat Kementerian Agama pada tahun 2019 dengan hasil penelitian penulis, disebabkan oleh adanya redaksi pertanyaan atau pernyataan dalam angket yang menyinggung aspekaspek ibadah (mengutamakan dimensi emik). Sedangkan pada penelitian yang penulis lakukan berusaha untuk menghindari pertanyaan atau pernyataan yang menjurus dan mengarahkan responden kepada pemahaman dan praktik ibadah masing-masing agama (menyeimbangkan dimensi emik dengan dimensi etik). Dari perspektif fakta sosial, hasil penelitian ini memotret lebih komprehensif tentang toleransi sebagai suatu realitas sosial yang dinamis, dipengaruhi oleh perkembangan zaman dan perubahan sosial, tidak hanya berdimensi emik, tetapi juga berdimensi etik.
\end{abstract}

Kata kunci: Antarumat Beragama; Indeks Toleransi; Perspektif Fakta Sosial

\begin{abstract}
This article aims to map and measure the tolerance index among religious communities in the East Lombok Regency. This research uses descriptive qualitative and survey methods. The data collection used a closed questionnaire technique and a focus group discussion technique. The data analysis used descriptive statistical methods and taxonomic analysis techniques. The tolerance index among religious communities in East Lombok Regency is the high category, with an average score of 3.79. Based on regions division, the lowest index score was obtained from the North region, namely Aikmel, Wanasaba, and Pringgabaya Districts, with a value of 3.28 , while the highest index score was obtained from the Sambelia District with a value of 3.87. Based on the tolerance mapping concept, which consists of five dimensions, the average score results are as follows: perception dimension 3.79, attitude dimension 3.11, cooperation dimension 2.95, government attitude dimension 3.74 , and expectation dimension to government 4.07. This data shows that the dimensions of cooperation and attitude have a low score in the sufficient category, while the other three are in the high category.
\end{abstract}

Keywords: Inter-Religious Communities; Tolerance Index; Social Fact Perspective

This is an open access article under the CC BY-SA license.

Copyright (C) 2021 by Author. Published by Universitas Pendidikan Ganesha.

\section{PENDAHULUAN}

Merujuk pada definisi konseptual atau operasional, baik dalam Bahasa Indonesia "toleran", bahasa Arab "asSamahah", maupun bahasa Latin "tolerare", toleransi mempunyai makna yang sangat luas seperti; memberikan izin, membolehkan, memaafkan, berlapang dada, murah hati dan kedermawanan. Jika dikaitkan dengan agama, maka toleransi berarti saling menghormati dan berlapang dada 
terhadap pemeluk agama lain, tidak memaksa mereka untuk mengikuti agamanya dan bahkan tidak mencampuri apapun dalam urusan agama masing-masing (Mursyid, 2018).

Toleransi adalah konsep modern untuk menggambarkan sikap saling menghormati dan saling bekerjasama di antara kelompok-kelompok masyarakat yang berbeda baik secara etnis, bahasa, budaya, politik, maupun agama. Oleh karena itu toleransi merupakan konsep mulia yang sepenuhnya menjadi bagian organik dari ajaran agama-agama, termasuk agama Islam. Konteks toleransi antarumat beragama, Islam memiliki konsep yang jelas yaitu "tidak ada paksaan dalam agama". Fakta-fakta sejarah Islam menunjukkan bahwa masalah toleransi dalam Islam bukanlah konsep asing. Toleransi adalah bagian integral dari Islam itu sendiri yang detail-detailnya kemudian dirumuskan oleh para ulama dalam karya-karya tafsir mereka (Aslati, 2012).

Toleransi antarumat beragama di Indonesia dikenal luas dengan istilah kerukunan hidup antarumat beragama. Istilah tersebut merupakan istilah resmi yang dipakai oleh pemerintah. Kerukunan hidup umat beragama merupakan salah satu tujuan pembangunan bidang keagamaan di Indonesia. Gagasan ini muncul terutama dilatarbelakangi oleh tegangnya hubungan antarumat beragama pada masa Orde Baru, yang disebabkan oleh berbagai faktor internal agama dan dipicu oleh faktorfaktor di luar agama. Namun ketegangan dan bahkan konflik tersebut berhasil ditekan oleh pemerintah waktu itu dengan pendekatan keamanan atau kekuasaan yang sentralistik dan topdown.

Salah satu konflik yang sering terjadi di Indonesia yakni konflik antarumat beragama. Konflik antarumat beragama ini dapat berupa konflik antaragama maupun konflik antaraliran tertentu dalam satu agama. Tentunya tidak mudah bagi bangsa Indonesia untuk merawat kebhinekaan dimana salah satu yang menjadi masalah krusial yakni isu toleransi umat beragama yang berada di Indonesia yang memiliki enam agama resmi atau diakui oleh pemerintah, menjadikan Indonesia salah satu negara yang memiliki berbagai macam agama (Muharam, 2020).

Konflik dan kekerasan antarumat beragama yang menonjol terjadi nyusul menyusul selama era reformasi bergulir. Mulai dari konflik Ambon tahun 1999, Poso selama kurun waktu 20002001, Sampit tahun 2000-2001, kekerasan terhadap jemaat Ahmadiyah di Denpasar tahun 2008, pengusiran anggota Gafatar tahun 2016, pembakaran Gereja Huria Kristen Indonesia di Aceh Singkil tahun 2016, kekerasan terhadap warga Syiah di Sampang tahun 2012, kasus Gereja Yasmin di Bogor tahun 2010, dan kerusuhan agama di Tolikara tahun 2015 (Erdianto, 2018).

Konflik antarumat beragama, secara keseluruhan di pulau Lombok pernah terjadi beberapa kali pasca reformasi seperti konflik antara masyarakat yang beragama Islam dan Kristen tahun 2000 yang terkenal dengan kasus 171 (kerusuhan tanggal 17 Januari 2000) di Kota Mataram, konflik antara kelompok Amfhibi dan komunitas Hindu di Kota Mataram tahun 1999, dan penyerangan warga Ahmadiyah tahun 2006 di Lombok Barat (Hasan \& Mursalin, 2011).

Adapun di Kabupaten Lombok Timur konflik antarumat beragama paling menonjol yang pernah terjadi adalah penyerangan dan pengusiran jamaah Ahmadiyah tahun 2000 di Selong dan terakhir terjadi penyerangan terhadap 24 anggota Jamaah Ahmadiyah di Desa Greneng Kecamatan Sakra Timur pada tanggal 19-20 Mei tahun 2018. Selebihnya konflik antarumat beragama sangat jarang terjadi, baik pada era sebelum reformasi maupun setelah era reformasi. Justru konflik yang sering terjadi yaitu intern umat Islam dengan 
berbagai latar belakang, motif, bentuk, dan eskalasi.

Realitas sosial kehidupan beragama masyarakat Lombok Timur di atas, jika ditilik dari perspektif fakta sosial lebih mendekati fakta empirik dan mencerminkan potret yang lebih menyeluruh tentang interaksi atau relasi antara individu dengan kelompok, antara kelompok dengan kelompok di tengah-tengah kehidupan masyarakat yang multikultural. Konteks ini, fakta sosial yang dimaksudkan adalah masyarakat sebagai suatu kenyataan (realitas) yang mandiri dalam arti lepas dari sikap individu yang ada di dalamnya. Keseluruhan kenyataan yang di dalam masyarakat dipandang sebagai struktur yang di dalamnya terdapat sistem pengorganisasian, norma-norma, pranata-pranata, nilainilai yang disepakati, pembagian kekuasaan dan kewenangan yang semuanya berpengaruh terhadap individu (Berger \& Luckmann, 1996; Campbell, 1994; Karman, 2015; Ritzer, 2003; Ritzer \& Goodman, 2008).

Kementerian Agama merilis Indeks Kerukunan Umat Beragama 2019. Berdasarkan survei Indeks KUB 2019 yang dilakukan Puslitbang Bimas Agama dan Layanan Keagamaan Badan Litbang dan Diklat Kementerian Agama ini, skor Indeks KUB pasca tahun 2019 ini menunjukkan angka rata-rata nasional pada poin 73,83 dari rentang 0-100, atau masuk kategori "sangat tinggi" dan "tinggi" (Marzuki, 2019). Adapun Nusa Tenggara Barat dengan penduduk mayoritas Islam, yang di dalamnya terdapat Kabupaten Lombok Timur dengan prosentase penduduk beragama Islam lebih dari $99 \%$, berada di bawah rata-rata nasional dengan skor indeks 70,7. Posisi NTB termasuk 6 provinsi dengan skor terendah, selain Riau, Banten, Jawa Barat, Sumatera Barat, dan Aceh.

Terkait dengan indeks kerukunan antarumat beragama yang dirilis Kementerian Agama pada tahun 2019, terdapat beberapa penelitian terdahulu dengan beragam sudut pandang dan pendekatan yang relevan dengan tulisan ini. Pertama, penelitian tentang toleransi antarumat beragama di Kota Bandung (Hermawati et al., 2017). Penelitian ini menggunakan pendekatan kuantitatif untuk mengukur nilai indeks toleransi melalui tiga dimensi utama yaitu persepsi, sikap dan kerjasama antarumat beragama. Hasil penelitian mereka menyimpulkan bahwa indeks toleransi antarumat beragama di Kota Bandung termasuk dalam kategori tinggi, yang mengindikasikan bahwa interaksi sosial antarumat beragama telah berlangsung secara baik dan berada dalam batasbatas jarak sosial yang wajar. Mayoritas responden memiliki persepsi positif terhadap toleransi antarumat beragama di Kota Bandung.

Kedua, penelitian oleh Kasir dan Palimbong (2019) tentang sikap toleransi antarumat beragama di Desa Sausu Kecamatan Sausu Kabupaten Parigi Moutong. Penelitian yang kedua ini menggunakan metode kualitatif dengan pendekatan deskriptif. Hasil penelitian ini menggambarkan bahwa wujud sikap toleransi antarumat beragama di Desa Sausu sudah cukup baik. Sikap toleransi yang diterapkan oleh masyarakat Desa Sausu diantaranya adalah menghormati keyakinan orang lain, memberikan kebebasan dalam menjalankan aktifitas keagamaan, saling membantu antarumat beragama, mengakui hak setiap orang dan saling mengerti, hidup rukun dan damai, tidak memusuhi, menjaga keamanan dan ketenangan.

Ketiga, penelitian tentang penanaman nilai toleransi antarumat beragama di kalangan masyarakat Kecamatan Mlati Kabupaten Sleman (Salim, 2017). Penelitian yang ketiga ini menggunakan metode kualitatif dengan pendekatan deskriptif. Hasil penelitian ini menggambarkan bahwa penanaman nilai toleransi antarumat beragama di kalangan masyarakat Kecamatan Mlati Kabupaten Sleman antara lain melalui peran aparat Desa, RT, RW dan tokoh agama di kalangan dusun. Peranan aparatur desa sangat penting dalam membentuk masayarakat yang dapat 
menanamkan nillai toleransi antarumat beragama, kegiatan seperti kerja bakti, perkumpulan warga setiap bulan akan menjadi wadah yang baik dalam menjalankan penanaman nilai toleransi tanpa membeda-bedakan agama.

Keempat, penelitian tentang kerukunan dalam komunikasi antarkelompok Agama Islam dan Hindu di Lombok (Sari et al., 2019). Penelitian yang keempat ini menggunakan metode kualitatif studi kasus. Hasil penelitian ini menyimpulkan bahwa proses kerukunan melibakan faktor waktu, perkawinan campur, nilai agama, dan luas ruang lingkup interaksi antarkelompok. Komunikasi memiliki peranan utama dalam terciptanya kerukunan karena merupakan syarat utama terjadinya interkasi. Hal ini juga dikuatkan dengan dasar pemikiran konsep teori CMM, dimana komunikasi melahirkan realitas sosial manusia.

Kelima, penelitian tentang toleransi antarumat beragama masyarakat perumahan (Faridah, 2013). Penelitian yang kelima ini sama dengan penelitian yang ketiga menggunakan metode kualitatif dengan pendekatan deskriptif. Hasil penelitian ini memaparkan bahwa bentuk toleransi yang dilakukan oleh warga beragama Islam dan warga beragama Kristen Katolik maupun Protestan berupa toleransi agama dan toleransi sosial. Toleransi agama dilakukan ketika berhubungan dengan kegiatan keagamaan masing-masing warga. Salah satunya ucapan selamat dan saling silaturahmi ketika salah satu umat beragama merayakan hari besar keagamaan. Sedangkan toleransi sosial diwujudkan ketika menyangkut kepentingan umum dan diluar kegiatan keagamaan misalnya melalui keegiatan kerjasama seperti kegiatan kerja bakti dan gotong royong.

Lima penelitian relevan terdahulu di atas mengungkap dan menganalisis toleransi dari satu sisi pendekatan atau metode yaitu hanya kuantitatif atau hanya kualitatif. Konteks hasil penelitian yang menggunakan pendekatan kuantitatif bertujuan mengukur indeks toleransi antarumat beragama pada satu kelompok masyarakat, sedangkan yang menggunakan pendekatan kualitatif bertujuan mendeskripsikan fenomena toleransi antarumat beragama pada satu kelompok masyarakat yang menjadi subjek penelitiannya.

Berdasarkan beragam makna toleransi di atas, berbagai fakta konflik yang berkaitan dengan toleransi dan hasil penelitian terdahulu yang relevan dengan tema tulisan ini, maka tujuan penelitian ini adalah untuk memaparkan dan menjelaskan indeks toleransi antarumat beragama di Kabupaten Lombok Timur menurut perspektif fakta sosial. Fokus penelitian ini berupaya menyempurnakan data-data kuantitatif (dimensi emik) terkait toleransi yang kurang mendalam secara kualitatif (dimensi etik), agar fakta sosial tentang toleransi antarumat beragama di Kabupaten Lombok Timur terpotret lebih utuh dan menyeluruh.

Hasil penelitian ini penting untuk disebarluaskan, supaya semua pihak terutama pemerintah daerah khususnya di Kabupaten Lombok Timur, memiliki bahan rujukan dan preferensi sebagai dasar menyusun program dan merumuskan kebijakan yang ramah terhadap pluralitas masyarakat, proporsional dan adil kepada semua entitas, sehingga mampu melakukan tindakan-tindakan antisipatif terhadap potensi-potensi konflik terselebung yang disebabkan atau berlabel keagamaan serta turunan-turunannya, sebelum terjadi tindakan-tindakan kekerasan oleh suatu kelompok masyarakat kepada kelompok masyarakat lainnya.

\section{METODE}

Pendekatan yang digunakan dalam penelitian ini adalah kuantitatif dengan metode survey. Penelitian survey merupakan jenis penelitian yang mengumpulkan informasi tentang karakteristik, tindakan, pendapat, dari sekelompok responden yang representatif yang dianggap sebagai populasi. Bahkan penelitian ini 
dikategorikan dengan istilah Cross Sectional Survey karena mencoba menggali isu yang bersifat temporer dengan pengumpulan data cukup satu kali (Widodo, 2008).

Berdasarkan definisi yang diberikan oleh Sugiyono (2013) bahwa populasi adalah wilayah generalisasi yang terdiri atas objek/subjek yang memiliki kuantitas dan karakteristik tertentu yang ditetapkan oleh peneliti untuk dipelajari dan kemudian ditarik kesimpulannya, maka yang menjadi populasi dalam penelitian adalah seluruh penduduk Kabupaten Lombok Timur dari berbagai latar belakang agama, suku, ras dan afiliasi organisasi. Adapun jumlah penduduk Lombok Timur saat penelitian dilakukan sebanyak; 1.295.785 Jiwa.

Karena jumlah populasi sangat besar, maka diperlukan teknik pengambilan sample yang relevan yaitu Cluster Sampling dan Purposive Sampling. Cluster sampling digunakan dengan pertimbangan lingkup wilayah sebagai sumber data penelitian yang sangat luas, sehingga ditetapkan pembagian 3 cluster menjadi bagian selatan, bagian tengah dan bagian utara Kabupaten Lombok Timur. Setelah cluster atau area penelitian ditentukan, maka dalam rangka menentukan jumlah atau kriteria responden penelitian maka teknik sampling yang digunakan adalah purposive sampling yaitu teknik penentuan sampel dengan pertimbangan tertentu, didasarkan atas ciri-ciri tertentu yang dipandang mempunyai sangkut paut yang erat dengan ciri-ciri populasi yang sudah diketahui sebelumnya.

Dari dua teknik sampling yang digunakan diperoleh sepuluh (10) kecamatan yang terdiri dari; Sakra, Sakra Barat, dan Keruak di bagian selatan; Masbagik, Selong, dan Suralaga di bagian tengah; Aikmel, Wanasaba, Pringgabaya, dan Sambelia di bagian utara. Dari masing-masing kecamatan diperoleh \pm 45 orang responden penelitian dengan kategori tokoh agama, tokoh masyarakat, tokoh pendidikan, tokoh pemuda, tokoh adat, dan tokoh perempuan, sehingga menghasilkan total responden sebanyak 415 orang.

Pengumpulan data dalam penelitian ini menggunakan teknik kuesioner atau angket tertutup yang diisi oleh 415 orang responden yang tersebar di 10 kecamatan, dan teknik Focus Group Discussion (Diskusi Kelompok Terfokus), dengan menghadirkan perwakilan masingmasing kecamatan dari semua unsur ketokohan yang sudah ditentukan. Adapun aspek-aspek yang ditanyakan dalam angket dan didiskusikan melalui FGD adalah dimensi persepsi masyarakat, sikap masyarakat, kerjasama antarkelompok masyarakat, sikap pemerintah, dan harapan terhadap pemerintah. Penggunaan teknik FGD dimaksudkan untuk menghimpun dan memperkaya datadata kualitatif.

Pengolahan dan analisis data kuantitatif menggunakan metode statistik deskriptif dengan bantuan program SPSS. Jawaban-jawaban responden yang diperoleh melalui kuesioner diolah untuk mendapatkan tabel frekuensi dan persentase dari setiap tanggapan responden. Secara bersamaan juga bisa diperoleh nilai skor rata-rata berupa mean dan median dari setiap variabel. Data lapangan kemudian dianalisisdengan teknik analisis domaindengan tujuan mencari makna umum atau gambaran umum masalah penelitian (Musfiqon, 2012) untuk memperkuat generalisasi pada saat penarikan kesimpulan.

\section{HASIL DAN PEMBAHASAN \\ Dimensi Emik Realitas Pemeluk Agama di Lombok Timur}

Kabupaten Lombok Timur adalah salah satu kabupaten yang berada di wilayah provinsi Nusa Tenggara Barat. Daerah ini memiliki jumlah penduduk sebanyak 1.295.785 jiwa dengan jumlah penduduk muslim 99,92\% sedangkan sisanya adalah beragama Hindu, Kristen, Budha dan lainnya masing-masing kurang dari $1 \%$. 
Berdasarkan data tersebut maka menjadi hal menarik untuk dikaji bagaimana tingkat kerukunan antarumat beragama di Kabupaten Lombok Timur yang mayoritas muslim terhadap penduduk yang minoritas.

Dari lima kriteria responden penelitian, kriteria berdasarkan agama yang dianut merupakan unsur yang paling kuat keterkaitannya dengan fokus tema tulisan ini. Adapun data hasil penelitian tentang kriteria responden berdasarkan agama terlihat pada Tabel 1.

Tabel 1. Deskripsi responden berdasarkan agama

\begin{tabular}{clrrrr}
\hline No & Agama & \multicolumn{1}{c}{ Frequency } & Percent & Valid Percent & Cumulative Percent \\
\hline 1 & Islam & 362 & 96.0 & 96.0 & 96.0 \\
2 & Kristen & 5 & 1.3 & 1.3 & 97.3 \\
3 & Hindu & 10 & 2.7 & 2.7 & 100.0 \\
& Total & 377 & 100.0 & 100.0 & \\
\hline
\end{tabular}

Sumber: Data lapangan yang sudah diolah

Data pada Tabel 1 termasuk sangat refresentatif sesuai dengan komposisi dan proporsi jumlah penganut agama di Lombok Timur. Konteks ini Islam merupakan pemeluk agama mayoritas dari seluruh responden dalam penelitian yakni sebesar 96\%, sedangkan Hindu 2.7\%, dan Kristen 1.3\%. Data tersebut sangat sesuai dengan kondisi atau keadaan jumlah penduduk Lombok Timur berdasarkan agama yang dianut. Badan Pusat Statistik Kabupaten Lombok Timur 2019 mencatat prosentase penduduk Kabupaten Lombok Timur yang beragama Islam sebesar $99.92 \%$.

Konteks perspektif fakta sosial pada kondisi empiris masyarakat Lombok Timur dari sisi realitas sosial keagamaan, temuan dan paparan data di atas tidak terbantahkan sebagai suatu kenyataan. Masyarakat Islam sebagai penduduk mayoritas Kabupaten Lombok Timur merupakan fakta sejarah sejak 5 abad yang lalu, dengan masuknya Islam ke Lombok Timur dari Jawa pasca berakhirnya kejayaan Majapahit, kemudian diikuti dengan berdirinya Kerajaan Selaparang Islam (Alfarisi et al., 2018; Jamaluddin, 2011b, 2011a).

Terkait relasi masyarakat Islam di Lombok Timur dengan penganut agama lain, sudah terjadi beberapa abad yang lalu, baik dalam konteks perdagangan maupun penjajahan, dimana faktor agama atau aliran-aliran keagamaan sangat mempengaruhi dinamika yang terjadi. Fakta sosial ini bermakna bahwa masyarakat Lombok Timur yang mayoritas beragama Islam memiliki pengalaman panjang dalam hal toleransi dengan pemeluk agama selain Islam, baik yang tinggal sementara maupun yang menetap menjadi penduduk Lombok Timur.

Dari dimensi emik, fakta sosial keberagamaan masyarakat Lombok Timur yang mayoritas beragaman Islam menunjukkan bahwa aspek perbedaan antarumat beragama di Lombok Timur relatif homogen, tetapi dari sisi aliran pemahaman dan organisasi keagamaan intern umat Islam justru sangat heterogen. Sehingga fenomena ini mengkonfirmasi bahwa toleransi antarumat beragama masyarakat Lombok Timur masuk kategori tinggi cenderung sangat tinggi, merupakan fakta sosial yang nyata.

\section{Indeks Toleransi antarumat Beragama di Lombok Timur}

Merujuk pada lima dimensi atau aspek sebagai indikator toleransi yang dikaji untuk memetakan indeks toleransi di Kabupaten Lombok Timur, maka dilakukan pemilahan antara pemetaan wilayah riset (cluster sampling) dengan peta konsep sebagai blueprint konstruksi toleransi masyarakat Lombok Timur secara keseluruhan. Perspektif demografi sosial, wilayah Lombok Timur dapat 
dipetakan menjadi tiga bagian secara geografis yaitu Selatan, Tengah, dan Utara. Wilayah Selatan diwakili oleh Kecamatan Keruak, Sakra dan Sakra Barat, wilayah Tengah diwakili oleh Kecamatan Selong, Suralaga, dan Masbagik, serta wilayah Utara diwakili oleh Kecamatan Aikmel, Wanasaba, Pringgabaya, dan Sambelia. Masingmasing wilayah dihuni oleh kelompok masyarakat dengan latar belakang sejarah, identitas, dan sub kultur yang berbeda serta dominan di wilayah masing-masing. Perspektif konsep toleransi yang dijabarkan menjadi lima dimensi yaitu; persepsi terhadap toleransi, sikap terhadap perbedaan, kerjasama dalam keberagaman, sikap pemerintah terhadap perbedaan masyarakat, dan harapan masyarakat terhadap pemerintah untuk membangun toleransi.

Adapun data hasil indeks toleransi antarumat beragama di Kabupaten Lombok Timur yang dihimpun dari 10 kecamatan mewakili wilayah selatan, tengah, dan utara dengan pertimbangan tingkat keberagaman dan struktur sosial masyarakat, ditunjukkan dalam Tabel 2.

Tabel 2. Skor indeks toleransi antarumat beragama berdasarkan wilayah

\begin{tabular}{clcccccc}
\hline & & \multicolumn{7}{c}{ Score Indeks } \\
\cline { 3 - 7 } No & Kecamatan & $\begin{array}{c}\text { Persepsi } \\
\text { Masyarakat }\end{array}$ & $\begin{array}{c}\text { Sikap } \\
\text { Masya- } \\
\text { rakat }\end{array}$ & $\begin{array}{c}\text { Kerja } \\
\text { Sama }\end{array}$ & $\begin{array}{c}\text { Sikap } \\
\text { Pemerintah }\end{array}$ & $\begin{array}{c}\text { Harapan } \\
\text { Kepada } \\
\text { Pemerintah }\end{array}$ & $\begin{array}{c}\text { Rata- } \\
\text { Rata }\end{array}$ \\
\hline 1 & Keruak & 3.92 & 3.21 & 3.14 & 3.97 & 4.21 & 3.69 \\
2 & Sakra & 3.87 & 3.11 & 2.96 & 3.89 & 4.25 & 3.62 \\
3 & Sakra Barat & 3.87 & 3.11 & 3.06 & 3.89 & 4.16 & 3.62 \\
4 & Masbagik & 3.87 & 3.11 & 3.04 & 3.89 & 4.16 & 3.62 \\
5 & Suralaga & 3.92 & 2.97 & 2.75 & 3.72 & 4.13 & 3.50 \\
6 & Selong & 3.88 & 3.15 & 3.04 & 3.65 & 4.10 & 3.56 \\
7 & Pringgabaya & 3.50 & 2.97 & 2.65 & 3.47 & 3.81 & 3.28 \\
8 & Aikmel & 3.50 & 2.97 & 2.65 & 3.47 & 3.81 & 3.28 \\
9 & Wanasaba & 3.50 & 2.97 & 2.65 & 3.47 & 3.81 & 3.28 \\
10 & Sambelia & 4.06 & 3.53 & 3.56 & 3.99 & 4.21 & 3.87 \\
& Rata-Rata & 3.79 & 3.11 & 2.95 & 3.74 & 4.07 & 3.79 \\
\hline
\end{tabular}

Sumber: Data lapangan yang sudah diolah

Indeks toleransi antarumat beragama di Kabupaten Lombok Timur secara keseluruhan berada pada kategori tinggi dengan skor rata-rata 3.79 . Adapun peta indeks toleransi antarumat beragama berdasarkan pemetaan tiga (3) wilayah di Kabupaten Lombok Timur, yaitu wilayah Selatan berada pada kategori tinggi dengan skor ratarata 3.64, wilayah Tengah berada pada kategori tinggi dengan skor rata-rata 3.56, dan wilayah Utara berada pada kategori tinggi dengan skor rata-rata 3.43. Skor hasil indeks toleransi antarumat beragama berdasarkan unit sampling yang disurvey, ditemukan data yang mengkomfirmasi bahwa skor indeks terendah diperoleh dari wilayah Kecamatan Aikmel, Wanasaba, dan Pringgabaya dengan nilai 3.28 , sedangkan skor indeks tertinggi diperoleh dari wilayah Kecamatan Sambelia dengan nilai 3.87.

Data di atas menggambarkan dan menjelaskan bahwa secara umum tingkat toleransi antarumat beragama di Kabupaten Lombok Timur berada pada kategori tinggi, meskipun terdapat perbedaan skor antara wilayah Selatan, Tengah, dan Utara. Perbedaan skor rata-rata wilayah Utara, Tengah, dan Selatan bersesuaian dengan prosentase jumlah penduduk yang menganut agama selain Islam. Di wilayah Utara penduduk non-Muslim $0.10 \%$, di Tengah $0.12 \%$, dan di Selatan $0.04 \%$.

Data hasil penelitian pada alinea di atas mengkomfirmasi dua hal yaitu, pertama; tingkat toleransi antarumat beragama di Kabupaten Lombok Timur tidak berbanding lurus dengan hasil 
survey yang dilakukan Puslitbang Bimas Agama dan Layanan Keagamaan Badan Litbang dan Diklat Kementerian Agama pada tahun 2019, yang menempatkan provinsi NTB berada di bawah rata-rata nasional dan masuk kelompok 6 provinsi terendah indeks toleransinya. Kedua; perbedaan skor rata-rata indeks antara wilayah Selatan, Tengah, dan Utara di Kabupaten Lombok Timur dapat menjadi cerminan adanya perbedaan tingkat toleransi antara kabupaten yang satu dengan yang lain di lingkup provinsi Nusa Tenggara Barat.

\section{Toleransi antarumat Beragama di Lombok Timur Perspektif Fakta Sosial}

Mengukur tingkat toleransi antarumat beragama di Nusa Tenggara Barat secara umum termasuk di Lombok Timur, berdasarkan aspek latar belakang sejarah, budaya, tradisi, tingkat heterogenitas, dan demografi sosial masyarakat (perspektif fakta sosial), akan lebih bermakna dan mendekati realitas sosial, jika dibandingkan dengan pendekatan wilayah administratif pemerintahan semata. Sudah menjadi pengetahuan umum bahwa NTB yang terdiri dari dua pulau, didiami oleh penduduk asli dengan tiga etnis mayoritas (Sasak, Samawa, dan Mbojo), disamping etnisetnis lain yang datang dari berbagai penjuru Nusantara bahkan dunia, memiliki keragaman budaya, bahasa, tradisi, adat-istiadat, dan agama. Sehingga multikulturalisme dan pluralitas sudah menjadi bagian inherent masyarakat NTB.

Untuk menghindari suatu konflik antarkelompok agama, sekte agama ataupun pandangan lain yang berkaitan dengan agama tentu saja perlu adanya kesadaran antarumat beragama yang dapat menekan atau meminimalisir adanya konflik. Menghidari suatu konflik atau sikap saling curiga antara satu dengan lainnya, membutuhkan adanya interaksi sosial yang lebih intens. Kesadaran sikap toleransi tidak begitu saja dapat dipahami oleh sebagian masyarakat Indonesia yang sangat multikultural. Bentuk interaksi sosial yang diakomodasi tentunya akan membentuk suatu toleransi (Casram, 2016).

Konteks kehidupan beragama, pokok pikiran di atas sejalan dengan pendapat yang menerangkan bahwa toleransi beragama adalah kesadaran seseorang untuk menghargai, menghormati, membiarkan, dan membolehkan pendirian, pandangan, keyakinan, kepercayaan, serta memberikan ruang bagi pelaksanaan kebiasaan, perilaku, dan praktik keagamaan orang lain yang berbeda atau bertentangan dengan pendirian sendiri dalam rangka membangun kehidupan bersama dan hubungan sosial yang lebih baik (Ghufron, 2016; Maulana, 2017).

Sebelum hasil indeks toleransi antarumat beragama di Kabupaten Lombok Timur dipaparkan, terlebih dahulu dijabarkan definisi tiga konsep pokok secara operasional dari lima dimensi yang diukur yaitu; persepsi, sikap, dan kerja sama. Persepsi adalah proses yang berkaitan dengan masuknya pesan atau informasi kedalam otak manusia, melalui persepsi manusia terus menerus mengadakan hubungan dengan lingkungannya. Hubungan ini dilakukan lewat inderanya, yaitu indera pengelihat, pendengar, peraba, perasa, dan pencium (Slameto, 2010). Sikap toleransi beragama adalah menerima, menghargai kebebasan dan keanekaragaman beragama yang menjadi suatu kepercayaan atau keyakinan dari golongan lain, tidak melakukan intervensi atau mencampuri urusan pihak lain (Bakar, 2016; Ramayulis, 2010).

Kerja sama merupakan fenomena yang pasti terjadi dalam berbagai kesempatan, dalam lapisan masyarakat dan dalam berbagai bentuk kegiatan. Melalui kerja sama manusia dapat membangkitkan dan menghimpun tenaga atau energy secara bersama yang kemudian disebut synergy (Ainurraahman, 2010). 
Indeks toleransi antarumat beragama di Kabupaten Lombok Timur berdasarkan konsep toleransi yang terdiri dari lima (5) dimensi, diperoleh hasil skor rata-rata sebagai berikut: dimensi persepsi $=3.79$, dimensi sikap $=3.11$, dimensi kerjasama $=2.95$, dimensi sikap pemerintah $=3.74$, dan dimensi harapan kepada pemerintah $=$ 4.07. Data ini menunjukkan bahwa dimensi kerjasama dan sikap memiliki skor rendah dengan kategori cukup, sedangkan tiga dimensi yang lain masuk kategori tinggi.

Lebih lanjut dapat dijelaskan berdasarkan indikator dimensi yang direspon bahwa rendahnya kerjasama dalam masyarakat dipengaruhi oleh kurang baiknya sikap antarsesama anggota masyarakat, walaupun persepsi masyarakat tentang toleransi tinggi atau baik dan penilaian masyarakat terhadap sikap pemerintah dalam membangun toleransi masih baik. Skor rata-rata dimensi harapan masyarakat kepada pemerintahuntuk membangun toleransi di Lombok Timur paling tinggi dibanding dimensi yang lain dengan kategori sangat tinggi, dipengaruhi oleh sikap pemerintah terkait toleransi yang dinilai masih baik oleh masyarakat.

Dari lima dimensi toleransi yang diukur, nilai tertinggi dengan skor 4.25 atau kategori sangat tinggi didapat dari dimensi "harapan kepada pemerintah" di wilayah Kecamatan Sakra. Data ini menggambarkan bahwa masyarakat di wilayah Kecamatan Sakra menaruh harapan yang sangat tinggi kepada pemerintah Lombok Timur untuk menciptakan situasi yang kondusif melalui berbagai kebijakan dan program dalam rangka membangun kehidupan beragama yang toleran. Berbagai kebijakan dan program tersebut harus berorientasi kepada misi pendeteksian dini potensi konflik, pencegahan gejala konflik, melokalisir eskalasi konflik jika terjadi, meminimalisir dampak konflik yang sudah terjadi, serta melaksanakan resolusi konflik secara komprehensif dan berkelanjutan.
Demikian halnya ketika dicermati
secara keseluruhan, dimensi
"kerjasama" mendapat skor paling rendah dibanding empat dimensi yang lain, dan berdasarkan pembagian wilayah, nilai terendah dengan skor 2.65 (kategori cukup) terjadi di wilayah utara yaitu; Kecamatan Aikmel, Wanasaba, dan Pringgabaya. Adapun rata-rata skor tertinggi secara keseluruhan sebesar 4.07 (kategori tinggi) didapat dari dimensi "harapan kepada pemerintah", dan berdasarkan pembagian wilayah skor tertinggi muncul di wilayah selatan yaitu Kecamatan Sakra dengan skor 4.25 (kategori sangat tinggi), serta menunjukkan peningkatan skor yang signifikan dari 4 dimensi lainnya.

Rendahnya nilai "kerjasama" antarumat beragama di Lombok Timur membutuhkan kajian lanjutan atau penelitian sejenis yang fokus menggali faktor-faktor penyebabnya. Salah satu hasil kajian yang dapat dijadikan asumsi awal adalah Model Kontruksi Kerukunan antarumat Beragama Berbasis Ikatan Kekerabatan Polong Renten di Kecamatan Pemenang Kabupaten Lombok Utara. Hasil kajian ini menunjukkan bahwa adanya ikatan kekerabatan "polong renten" dapat dijadikan sebagai tali pengikat persaudaraan diantara umat beragama, saling hormat menghormati, bekerja sama dalam menyelesaikan persoalanpersoalan antarumat beragama, yang diperkuat oleh FKUB sebagai forum kerukunan umat beragama di wilayah tersebut (Maretha, 2015). Artinya sistem kekerabatan dan nilai-nilai kearifan lokal suatu masyarakat dapat mempengaruhi secara kultural tingkat toleransi masyarakat di suatu wilayah atau daerah. Konteks ini eksistensi dan fungsi FKUB secara struktural juga berkontribusi terhadap toleransi antarumat beragama.

Potensi kolaborasi revitalisasi kearifan lokal berbasis agama sangat mungkin dikembangkan menjadi bagian dari upaya resolusi konflik dan prakarsa perdamaian antarumat beragama, tanpa harus bertabrakan dengan 
kaidah-kaidah Islam sebagai agama mayoritas masyarakat Lombok. Pilihan penguatan dapat dilakukan dengan banyak cara sesuai kultur lokal, mulai dari kegiatan sangkep (pertemuan, seminar), dan gundem (musyawarah) yang difasilitasi oleh pemerintah atau lembaga swadaya masyarakat (Zuhdi, 2018). Budaya lokal dan agama mampu membentuk masyarakat yang harmonis, tidak lain tercipta melalui banyak ruang toleransi bernuansa agama dan ruang toleransi bernuansa budaya lokal. Ruang-ruang tersebut memberikan sumbangan terbesar dalam membentuk masyarakat yang harmonis. Dikatakan demikian karena; pertama, ruang-ruang tersebut menjadi titiktemu anggota masyarakat dari berbagai latar belakang status sosial, suku, agama, ideologi, dan politik yang terjadi di masa lalu. Kedua, nilai lokal atau kearifan lokal dapat berfungsi sebagai norma-norma sosial yang memiliki pengaruh kuat dalam mengatur sikap dan perilaku masyarakat (Kholidi, 2018).
Perolehan skor atau nilai sikap yang lebih tinggi dibandingkan kerjasama sejalan dengan pernyataan bahwa sikap mengayomi pemeluk agama lain dapat menjadikan pemeluk agama minoritas merasa aman dan terlindungi dari ancaman radikalisme. Di tempat-tempat tertentu di Mataram memang ditemukan ada penganut agama tertentu lebih besar jumlahnya dari yang lain dan itu umumnya umat Islam, tetapi tidak ada tindakantindakan dari penganut mayoritas yang melakukan tindakan atau tekanan kepada yang lainnya, malahan kelompok minoritas justru merasa aman dan nyaman berdampingan dengan tetangganya yang muslim (Kholidi, 2018; Muhtar \& Jihad, 2019).

$$
\text { Kriteria subjek penelitian }
$$

berdasarkan agama yang dianut merupakan unsur yang paling kuat keterkaitannya dengan fokus tema artikel ini, maka indeks toleransi antarumat beragama di Lombok Timur dalam perspektif fakta sosial tercermin pada Tabel 3.

Tabel 3. Skor Rata-Rata Indeks Toleransi antarumat Beragama Berdasarkan Agama yang Dianut

\begin{tabular}{cccccccc}
\hline & \multicolumn{6}{c}{ Score Indeks } \\
\cline { 3 - 7 } No & Agama & $\begin{array}{c}\text { Persepsi } \\
\text { Masyarakat }\end{array}$ & $\begin{array}{c}\text { Sikap } \\
\text { Masyarakat }\end{array}$ & $\begin{array}{c}\text { Kerja } \\
\text { sama }\end{array}$ & $\begin{array}{c}\text { Sikap } \\
\text { Pemerintah }\end{array}$ & $\begin{array}{c}\text { Harapan } \\
\text { Kepada } \\
\text { Pemerintah }\end{array}$ & $\begin{array}{c}\text { Rata- } \\
\text { Rata }\end{array}$ \\
\hline 1 & Islam & 3.88 & 3.20 & 3.01 & 3.86 & 4.15 & 3.62 \\
2 & Kristen & 4.16 & 4.02 & 3.98 & 3.72 & 4.84 & 4.14 \\
3 & Hindu & 4.24 & 417 & 415 & 3.86 & 4.56 & 4.20 \\
\multicolumn{2}{l}{ Rata-rata } & 4.09 & 3.80 & 3.71 & 3.81 & 4.52 & \\
\hline
\end{tabular}

Sumber: Data lapangan yang sudah diolah

Menilik tabel di atas, skor ratarata indeks toleransi masyarakat Lombok Timur yang beragama Islam sebesar 3.36, menunjukkan skor paling rendah diantara tiga kelompok agama yang berbeda. Pada kelompok masyarakat yang beragama Kristen diperoleh skor 4.14, dan kelompok masyarakat yang beragama Hindu memperoleh skor 4.20, menunjukkan skor paling tinggi dibandingkan dengan dua kelompok masyarakat pemeluk agama Islam dan Kristen. Adapun dari segi dimensi kajian, persepsi masyarakat untuk semua pemeluk agama diperoleh skor rata-rata sebesar 4.09, dimensi sikap masyarakat diperoleh skor rata-rata 3.80, dimensi kerjasama diperoleh rata-rata skor 3.71, yang menampilkan skor paling rendah, dimensi sikap pemerintah diperoleh skor 3.81, dan dimensi harapan kepada pemerintah diperoleh skor rata-rata 4.52, yang menunjukkan rata-rata skor paling tinggi dibandingkan dengan dimensi lainnya.

Data yang menggambarkan indeks toleransi antarumat beragama di 
Kabupaten Lombok Timur di atas menjelaskan dan mengkomfirmasi adanya perbedaan tingkat toleransi antara kelompok masyarakat yang beragama Islam, Kristen, dan Hindu. Hasil penelitian menunjukkan bahwa masyarakat Muslim di Lombok Timur memiliki toleransi paling rendah dibandingkan dengan masyarakat yang beragama Kristen dan Hindu. Data ini menunjukkan adanya kesamaan atau fenomena yang berbanding lurus dengan hasil survey yang dilakukan Puslitbang Bimas Agama dan Layanan Keagamaan Badan Litbang dan Diklat Kementerian Agama pada tahun 2019, dimana provinsi NTB masuk kelompok 6 provinsi terendah indeks toleransinya bersama Riau, Banten, Jawa Barat, Sumatera Barat, dan Aceh, karena 6 provinsi ini mayoritas penduduknya beragama Islam (di atas 85\%) (Muhtar \& Jihad, 2019).

Perbedaan tingkat toleransi antarumat beragama antara hasil survey Puslitbang Bimas Agama dan Layanan Keagamaan Badan Litbang dan Diklat Kementerian Agama pada tahun 2019 dengan hasil penelitian pada artikel ini, menurut analisa penulis disebabkan oleh adanya item-item pertanyaan atau pernyataan dalam angket yang disebarkan menyinggug aspek-aspek yang berkaitan dengan ibadah. Padahal secara konsep operasional variabel dan indikator, instrument pengumpulan data yang penulis gunakan tidak ada perbedaan, serta validitas instrumentnya teruji secara metodologis. Perbedaannya terletak pada upaya kami sebagai penulis atau peneliti untuk menghindari pertanyaan atau pernyataan yang menjurus dan mengarahkan responden kepada pemahaman dan praktik ibadah masing-masing agama.

Analisa penulis pada alinea di atas didasarkan pada pertimbangan dan pendekatan dimensi etik keberagamaan seseorang atau kelompok, agar tidak terjadi pembiasan makna, subjek penelitian memberikan data dan informasi apa adanya berdasarkan pemahaman, pengalaman, bahkan keyakinan agama yang dianutnya. Konteks fakta sosial, bukan hanya realitas terhampar yang dapat dipotret, tetapi pandangan dan sikap yang terpendam juga dapat diungkap.

Meskipun ada perbedaan hasil penelitian penulis dengan hasil survey Puslitbang Bimas Agama dan Layanan Keagamaan Badan Litbang dan Diklat Kementerian Agama pada tahun 2019, tentang indeks toleransi antarumat beragama, namun dalam hal lebih rendahnya tingkat toleransi kelompok masyarakat Islam di Kabupaten Lombok Timur dibandingkan dengan kelompok masyarakat dari pemeluk agama lain, memiliki kesamaan atau menguatkan hasil survey tersebut, yang menunjukkan bahwa indeks toleransi antarumat beragama di provinsi yang mayoritas penduduknya muslim di bawah rata-rata nasional dan masuk kelompok bawah. Hal yang sama juga terbukti dari hasil temuan peneliti di lingkup daerah Kabupaten Lombok Timur dengan prosentase penduduk muslim paling tinggi di wilayah Nusa Tenggara Barat yaitu 99.92\%.

\section{SIMPULAN DAN SARAN}

Dari dimensi emik, keberagamaan masyarakat Lombok Timur yang mayoritas beragaman Islam menunjukkan bahwa aspek perbedaan antarumat beragama di Lombok Timur relatif homogen, tetapi dari sisi aliran pemahaman dan organisasi keagamaan intern umat Islam justru sangat heterogen. Sehingga fenomena ini mengkonfirmasi bahwa toleransi antarumat beragama masyarakat Lombok Timur masuk kategori tinggi cenderung sangat tinggi, merupakan fakta sosial yang nyata.

Perbedaan tingkat toleransi antarumat beragama antara hasil survey Puslitbang Bimas Agama dan Layanan Keagamaan Badan Litbang dan Diklat Kementerian Agama pada tahun 2019 dengan hasil penelitian penulis, disebabkan oleh adanya redaksi pertanyaan atau pernyataan dalam angket yang menyinggung 
aspek-aspek ibadah (ritual). Sedangkan pada penelitian yang penulis lakukan berusaha untuk menghindari pertanyaan atau pernyataan yang menjurus dan mengarahkan responden kepada pemahaman dan praktik ibadah masing-masing agama.

Dari perspektif fakta sosial, hasil penelitian ini memotret lebih komprehensif tentang toleransi sebagai suatu realitas sosial yang dinamis, dipengaruhi oleh perkembangan zaman dan perubahan sosial, tidak hanya berdimensi emik, tetapi juga berdimensi etik. Oleh karena itu penting dilakukan penelitian selanjutnya dari perspektif definisi sosial dan perilaku sosial, supaya potret toleransi pada suatu kelompok masyarakat dan daerah bisa lebih utuh-menyeluruh.

\section{DAFTAR PUSTAKA}

Ainurraahman. (2010). Belajar dan Pembelajaran. Alfabeta.

Alfarisi, S., Tohri, A., Habibuddin, \& Hanapi. (2018). Tuan Guru: Gerakan Revolusi Sosial Masyarakat Sasak. Lombok Institut, Pemerintah Daerah Lombok Timur, Kalam Semesta.

Aslati, A. (2012). Toleransi Antar Umat Beragama dalam Perspektif Islam (suatu Tinjauan Historis). TOLERANSI: Media IImiah Komunikasi Umat Beragama, 4(1), 52-58.

Bakar, A. (2016). Konsep toleransi dan kebebasan beragama. Toleransi: Media IImiah Komunikasi Umat Beragama, 7(2), 123-131.

Berger, P. L., \& Luckmann, T. (1996). The Social Construction of Reality.

Campbell, T. (1994). Tujuh Teori Sosial: Sketsa, Penilaian, Perbandingan (Terjemahan $F$. Budi Hardiman). Kanisius.

Casram, C. (2016). Membangun sikap toleransi beragama dalam masyarakat plural. Wawasan: Jurnal IImiah Agama Dan Sosial Budaya, 1(2), 187-198.

Erdianto, K. (2018). Konflik dan Pelanggaran HAM: Catatan Kelam 20 Tahun Reformasi.
Https://Nasional.

Kompas.Com/Jeo/ Konflik-DanPelanggaran-Ham-Catatan-Kelam20-Tahun-Reformasi. Diakses 20 Agustus 2019.

Faridah, I. F. (2013). Toleransi Antarumat Beragama Masyarakat Perumahan. Komunitas: International Journal of Indonesian Society and Culture, 5(1), 14-25.

Ghufron, M. N. (2016). Peran Kecerdasan Emosi Dalam Meningkatkan Toleransi Beragama. Fikrah, 4(1), 138-153.

Hasan, B., \& Mursalin, A. (2011). Konflik Komunal Mengatasnamakan Agama di Indonesia: Analisis Terhadap Konflik Ahmadiyah dalam Pemberitaan Media, 2005-2011. Kontekstualita: Jurnal Penelitian Sosial Keagamaan, 26(1), 71-115. Hermawati, R., Paskarina, C., \& Runiawati, N. (2017). Toleransi antar umat beragama di Kota Bandung. Umbara, 1(2), 105-124.

Jamaluddin. (2011a). Islam Sasak: Sejarah Sosial Keagamaan di Lombok (Abad XVI-XIX). IndoIslamika, 1(1), 63-88.

Jamaluddin. (2011b). Sejarah Sosial Islam di Lombok Tahun 17401935: Studi Kasus Terhadap Tuan Guru. Puslitbang Lektur dan Khazanah Keagamaan Badan Litbang dan Diklat Kementrian RI.

Karman. (2015). Konstruksi Realitas Sosial Sebagai Gerakan Pemikiran (Sebuah Telaah Teoretis Terhadap Konstruksi Realitas Peter L. Berger). Jurnal Penelitian Dan Pengembangan Komunikasi Dan Informatika, 5(3), 11-23.

Kasir, A. (2019). Sikap Toleransi Antar Umat Beragama di Desa Sausu Kecamatan Sausu Kabupaten Parigi Moutong. EDU CIVIC, 7(2), 12-20.

Kholidi, A. K. (2018). Harmoni Masyarakat Islam dan Hindu di Desa Lingsar, Kabupaten Lombok Barat (Ditinjau dari Perspektif Pierre Bourdieu). Palita: Journal of Social Religion Research, 3(1), 
35-54.

Marzuki, M. (2019). Executive Summary: Survey Indeks Kerukunan Umat Beragama Tahun 2019.

https://simlitbangdiklat.kemenag.g

o.id/simlitbang/spdata/upload/doku

men-

penelitian/1586237704Exsum_Pe nelitian_KUB_2019.pdf

Maulana, M. A. (2017). Pelaksanaan Toleransi Keberagamaan Dalam Proses Pendidikan Agama Di Geeta School Cirebon. OASIS: Jurnal IImiah Kajian Islam, 1(2), 17-38.

Muharam, R. S. (2020). Membangun toleransi umat beragama di indonesia berdasarkan konsep deklarasi kairo. Jurnal HAM, 11(2), 269-283.

Muhtar, F. R., \& Jihad, S. (2019). Ketahanan Umat Beragama Dalam Mencegah Radikalisme di Kota Mataram Nusa Tenggara Barat. Jurnal Ketahanan Nasional, 25(1), 56-72.

Mursyid, S. (2018). Konsep Toleransi (Al-Samahah) Antar Umat Beragama Perspektif Islam. Aqlam: Journal of Islam and Plurality, 1(2), 35-51.

Musfiqon. (2012). Metodologi Penelitian Pendidikan (Cet. I). Prestasi Pustaka.

Ramayulis. (2010). IImu Pendidikan Islam. Kalam Mulia.

Ritzer, G. (2003). Sosiologi ilmu Pengetahuan Berparadigma Ganda (Terjemahan Alimandan). Raja Grafindo.

Ritzer, G., \& Goodman, D. J. (2008). Teori Sosiologi: Dari Teori Sosiologi Klasik Sampai Perkembangan Mutakhir Teori Sosial Postmodern (Terjemahan Nurhadi). Kreasi Wacana.

Salim, A. N. (2017). Penanaman Nilai Toleransi Antar Umat Beragama di Kalangan Masyarakat Kecamatan Mlati Kabupaten Sleman. Fakultas Keguruan dan Ilmu Pendidikan Universitas PGRI Yogyakarta.

Sari, W. P., Paramita, S., \& Azeharie,
S. (2019). Kerukunan Dalam Komunikasi Antar Kelompok Agama Islam Dan Hindu Di Lombok. Jurnal Penelitian Komunikasi Dan Opini Publik, 23(1), 63-75.

Slameto. (2010). Belajar dan Faktorfaktor yang Mempengaruhinya. Rineka Cipta.

Sugiyono. (2013). Metode Penelitian Kuantitatif, Kualitatif, dan $R \& D$. Alfabeta.

Widodo, T. (2008). Metode Penelitian Kualitatif. Universitas Sebelas Maret Press.

Zuhdi, M. H. (2018). Kearifan Lokal Suku Sasak Sebagai Model Pengelolaan Konflik Di Masyarakat Lombok. Mabasan, 12(1), 64-85. https://doi.org/https://doi.org/10.26 499/mab.v12i1.34 